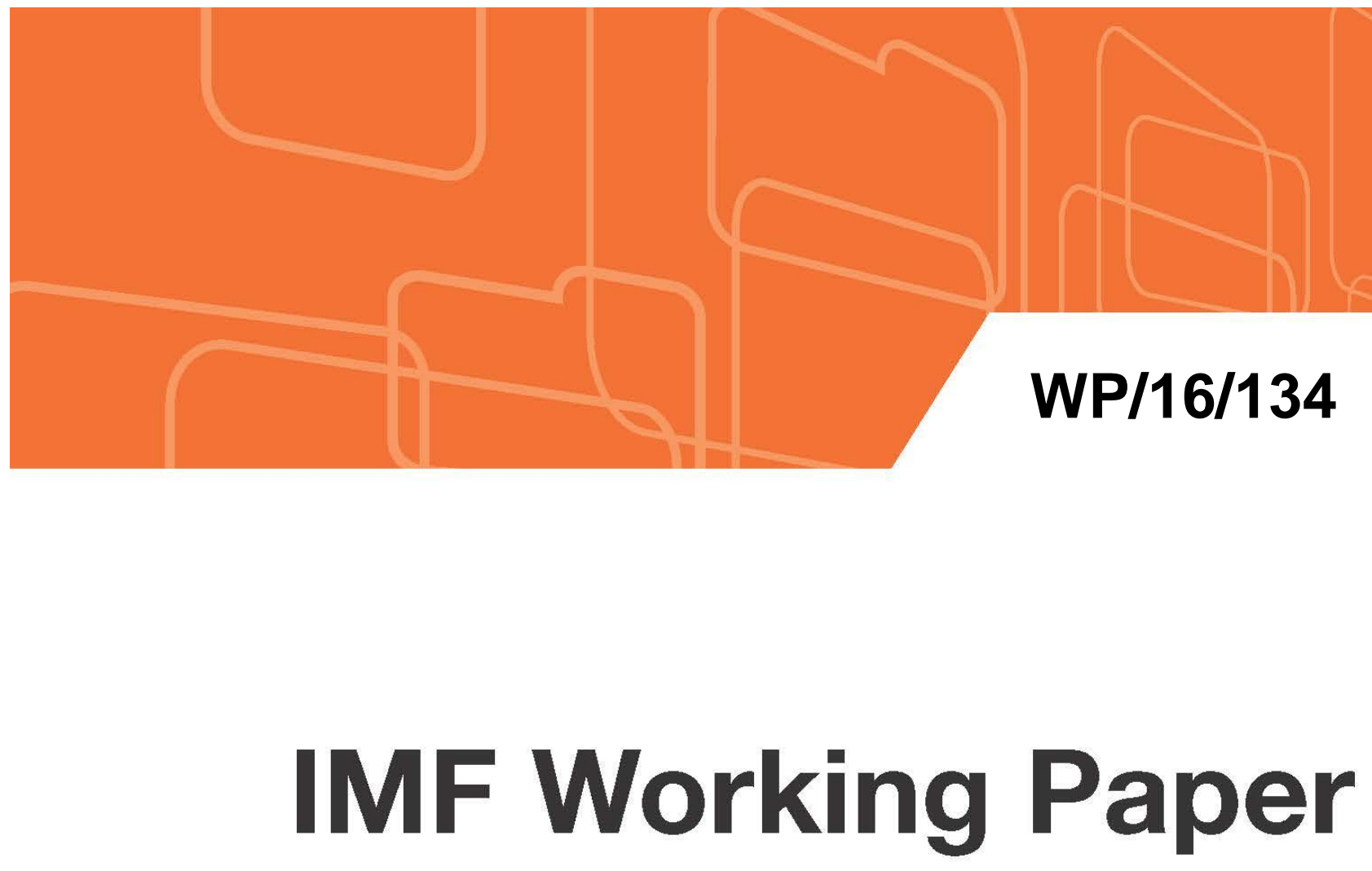

\title{
INSOLVENCY AND ENFORCEMENT REFORMS IN ITALY
}

by José Garrido

IMF Working Papers describe research in progress by the author(s) and are published to elicit comments and to encourage debate. The views expressed in IMF Working Papers are those of the author(s) and do not necessarily represent the views of the IMF, its Executive Board, or IMF management.

I N T E R N A T I O 


\title{
IMF Working Paper
}

European and Legal Departments

\section{Insolvency and Enforcement Reforms in Italy}

\section{Prepared by José Garrido}

\author{
Authorized for distribution by Rishi Goyal and Yan Liu
}

July 2016

\section{IMF Working Papers describe research in progress by the author(s) and are published to elicit comments and to encourage debate. The views expressed in IMF Working Papers are those of the author(s) and do not necessarily represent the views of the IMF, its Executive Board, or IMF management.}

\begin{abstract}
Italian banks are burdened with high levels of nonperforming loans, the cleanup of which depends in important part on the efficiency of insolvency and enforcement processes. Traditionally, these processes in Italy have taken very long, hampering the timely cleanup of balance sheets. In response, the authorities have legislated a number of measures. This paper explores the recent insolvency and enforcement reforms and the remaining challenges. These reforms introduce important positive changes that are expected to yield full benefits over the medium to long term. The efficacy of the reforms, including to deal with the current stock of high nonperforming loans, can be enhanced by introducing effective out-of-court enforcement mechanisms, supplemented by a more intensive use of informal and hybrid debt-restructuring solutions. Moreover, there is an urgent need to rationalize the system, which over the years has become very complex and intricate.
\end{abstract}

JEL Classification Numbers: G33, K22.

Keywords: private debt, insolvency, debt restructuring, enforcement of debt.

Author’s E-Mail Address: jgarrido@imf.org 


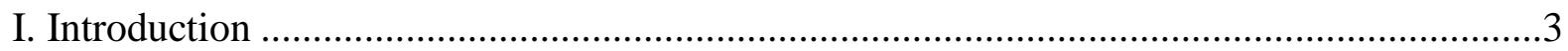

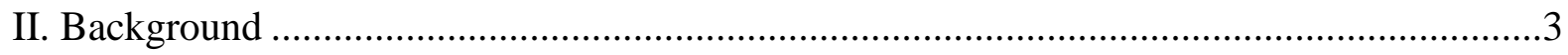

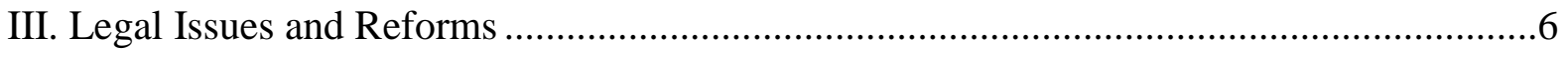

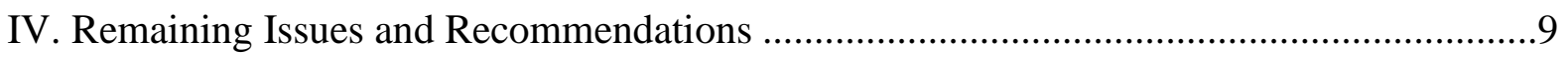

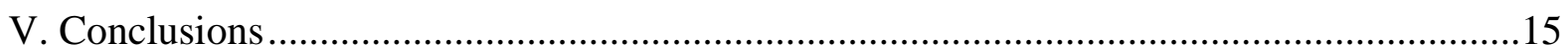

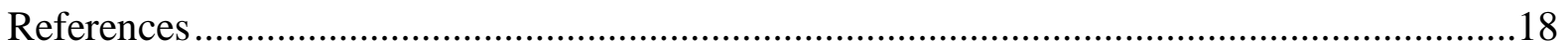

Tables

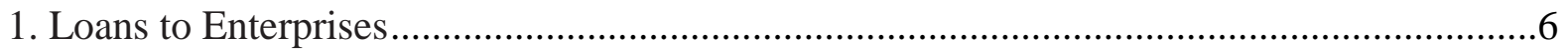

Figures

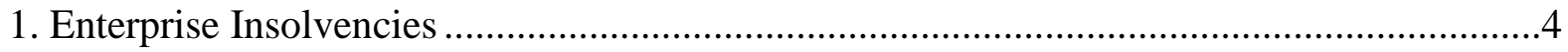

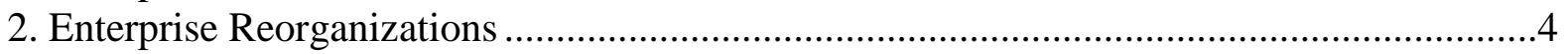

3. Time for Adjudication of a Commercial Dispute .....................................................5

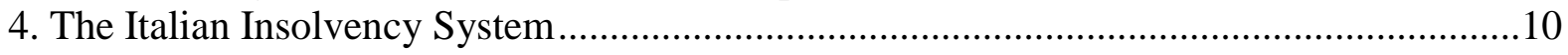

Boxes

1. Insolvency Reforms in Italy (2005-2016) .............................................................

2. Enforcement of Secured Credit in Insolvency-Key Elements in Compared Systems ......16

3. Individual Enforcement of Secured Credit—Key elements in Compared Systems ............17 


\section{INTRODUCTION}

High levels of nonperforming loans in the Italian banking sector are connected to the situation of distress in the corporate sector. The crisis has resulted in an increase in the indebtedness of enterprises (including also micro-enterprises and SMEs). This has led to record numbers of insolvency procedures in Italy, with a historic peak being achieved in 2014. The distressed situation of Italian enterprises is largely responsible for the high levels of nonperforming loans (NPLs) on banks' balance sheets.

To address the NPL problem, the reform of the insolvency and enforcement regime has become a priority for the government. Addressing the high levels of NPLs requires a comprehensive strategy that includes supervisory, tax and legal measures (IMF, 2015a; IMF, 2015b; and Aiyar and others, 2015). The reform of the insolvency system - and also of the enforcement mechanisms available to creditors - represents a fundamental part of their strategy. The Italian authorities have undertaken successive reforms of the insolvency and enforcement framework in the last few years, although the full effect of these reforms is expected to be realized only over the medium to long term. The objective of the reforms has been to achieve a faster resolution of insolvency and swifter enforcement that could lead to efficient outcomes for creditors and all interested parties. However, the changes to the insolvency framework have generally been piecemeal, raising the need for a systematic reform, as the government indeed recognized when appointing the Rordorf Commission in 2015 that was aimed at rationalizing and simplifying the insolvency framework.

This paper analyzes the insolvency and enforcement reforms in Italy, their potential role in addressing corporate debt distress, and remaining challenges. The first section provides background by summarizing the situation of corporate debt in Italy, its importance in terms of the NPL stock, and the processing of insolvency cases in the Italian courts. The second section provides information about key changes introduced by the various insolvency and enforcement reforms adopted in the last year. The third section discusses remaining issues in the insolvency and debt enforcement framework, and specifically how the insolvency and enforcement regime could be further reinforced to increase the satisfaction of secured and unsecured creditors. The paper concludes with a summary of policy recommendations to increase the effectiveness of corporate debt resolution.

\section{BACKGROUND}

The long economic crisis has resulted in widespread debt distress among Italian enterprises. ${ }^{1}$ Despite a small reduction in leverage levels, ${ }^{2}$ a high percentage of companies

\footnotetext{
${ }^{1}$ See N. Budina, S. Lanau, and P. Topalova (2015).

${ }^{2}$ See Banca d'Italia (2016): “The reduction of corporate indebtedness is proceeding gradually. Over the first nine months of 2015, the amount of firms' financial debt declined both in absolute terms and in proportion to GDP (...). Leverage came down by 2 percentage points with respect to the end of 2014 ."
} 
suffer from over-indebtedness and have difficulty in repaying their loans. The number of insolvencies has stabilized after the peak of 2014 (see Figure 1), but remains almost double that of precrisis times.

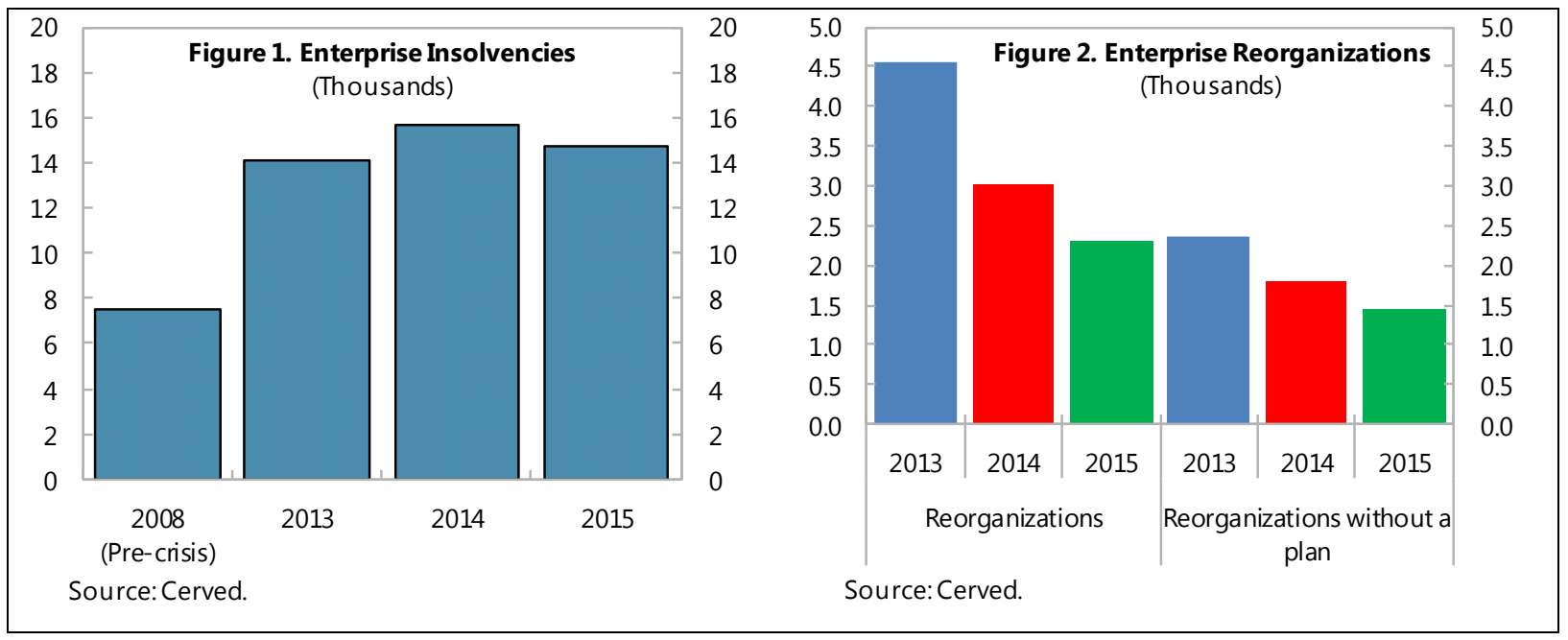

The situation of corporate debt distress has translated into a high level of NPLs in the Italian banking sector. NPLs on Italian banks' balance sheets amounted to $€ 360$ billion at the end of 2015, representing 18.1 per cent of total loans. ${ }^{3}$ Loans to enterprises represent the bulk of NPLs, amounting to about $€ 250$ billion, ${ }^{4}$ of which $€ 154$ billion represent loans of the lowest category (legal status, or sofferenze). This represents, in turn, 29.4 percent of all bank exposures with enterprises.

\section{It is generally recognized that there are three basic approaches to tackle nonperforming} loans: sale, restructuring, and collection. The collection approach, in particular, is dependent on the efficiency of the legal system to provide the creditor with tools to enforce its loan, inside or outside insolvency, within a reasonable time. Traditionally, however, the Italian legal system has not offered creditors the opportunity to recover their claims in a timely manner - although estimates vary, it is generally recognized that the Italian system is the most prone to delay among all major European countries (see Figure 3). ${ }^{5}$ Although the

\footnotetext{
${ }^{3}$ Source: Banca d'Italia (2016).

${ }^{4}$ Source: Banca d'Italia (2016). The amount of enterprise NPLs represents 25.4 percent of total loans granted to enterprises (983 billion euros).

${ }^{5}$ The problems in the performance of the civil justice system represent an obstacle to economic growth in Italy (see Esposito, G. L., Lanau, S., Pompe, S. (2014)). Data show that Italy has the slowest court system in the adjudication of civil and commercial disputes of all major economies in the EU (according to the European Justice Scoreboard 2016, only Malta and Cyprus have less efficient systems for the resolution of civil and commercial cases). Also according to available data, a civil or commercial case is resolved in first instance on an average of more than 500 days from the start of the process. In addition, appeals can multiply the average time by more than three times for the full completion of the process (around six years).
} 
reforms of the insolvency legislation have brought the Italian framework closer to international best practices, their impact remains to be assessed. ${ }^{6}$

\section{The major difficulty in resolving corporate indebtedness is the time of recovery of claims and the low rates of recovery. There are} different estimates on the length of enforcement and insolvency procedures. However, there is consensus that both types of procedures have ordinarily lasted more than four years: many commentators have noted that an insolvency case can be concluded within six years, and an enforcement action can take up to nine years. ${ }^{7}$ The latest data provided by the Ministry of

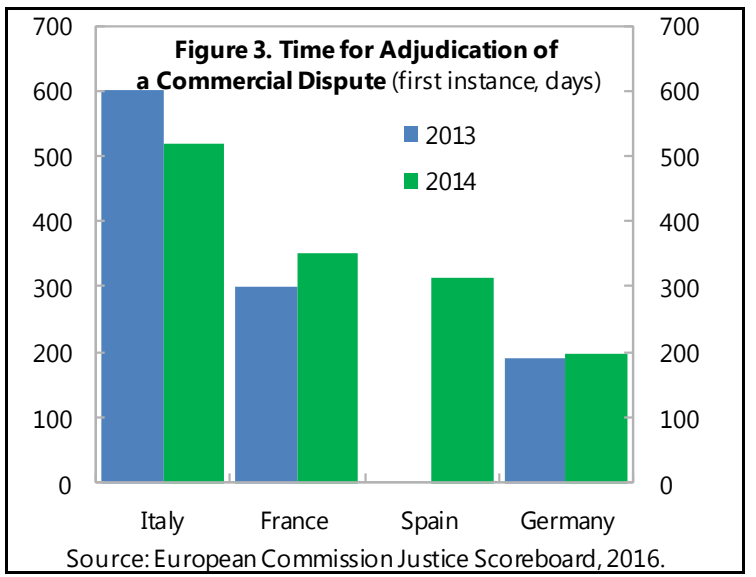

Justice show that insolvency processes last an average of 7.5 years (2,760 days). The recovery rates are low, owing to the length of the procedure, but also because of the expenses incurred. ${ }^{8}$ According to a recent survey conducted by the Bank of Italy, recovery rates for all debt restructuring, enforcement, and insolvency procedures concluded in the period 2011-14 averaged 41 percent of the amount of the claims, with about 50 percent for property foreclosure sales, and just below 30 percent for bankruptcies. Most recoveries occurred in the five years following the start of the liquidation. The survey also showed that debt restructurings are rarely durable: numerous restructuring agreements ended with the liquidation of the debtor business, and the rate of success for restructurings was low. ${ }^{9}$ The recovery of claims depends on the legal position of creditors: bank loans secured by collateral (including loans to enterprises and to consumers) amounts to $€ 160$ billion, which represents a bit less than one half of the total nonperforming exposures in the financial

\footnotetext{
${ }^{6}$ Data provided by the Italian Ministry of Justice evidence some reduction as a result of the reforms and implementing actions: time to resolve appeals was reduced by seven months in the period 2012-2015; and the time to resolve commercial disputes was shortened by four months in the same period.

${ }^{7}$ Marcucci, M., Pischedda, A. and Profeta, V. (2015) estimate that an insolvency process would take six years and an enforcement action more than four years. Cerved (2015) estimates that a bankruptcy process or enforcement action takes 7.3 years.

${ }^{8}$ According to a recent survey conducted by Bank of Italy staff among financial institutions, the average recovery rate in 2014 was 28 percent of the loans in liquidations, and 32 percent of the loans in reorganizations (see Carpinelli, L., and others, 2016). The length and cost of the procedures are mentioned by respondents, and are also frequently mentioned in the legal and economic literature. There is an additional factor: the market for real estate is depressed, so there are few chances of selling property at process that correspond with the precrisis market valuations. There are no official statistical data on credit recoveries in insolvency: the elaboration of statistical data could benefit from the use of modern information technologies in civil procedure.

${ }^{9}$ See Carpinelli, L., and others (2016): according to the results of the survey, just over 10 percent of enterprise restructurings had resulted in a return to financial equilibrium, and another 5 percent ended with the acquisition or merger of the enterprise.
} 
system. ${ }^{10}$ Regarding loans to enterprises, secured loans represent $€ 119$ billion out of $€ 250$ billion in nonperforming exposures (see Table 1).

\begin{tabular}{|c|c|c|c|c|c|c|}
\hline \multicolumn{7}{|c|}{$\begin{array}{l}\text { Table 1. Loans to Enterprises } \\
\text { Billions of euros and percentages, December } 2015\end{array}$} \\
\hline & $\begin{array}{c}\text { Gross } \\
\text { Exposure }\end{array}$ & $\begin{array}{c}\text { Net } \\
\text { Exposure }\end{array}$ & Collateral & $\begin{array}{c}\text { Pers. } \\
\text { Guarantee }\end{array}$ & $\begin{array}{c}\text { Coverage } \\
\text { ratio }\end{array}$ & $\begin{array}{c}\text { Cov. ratio } \\
\text { unsecured loans }\end{array}$ \\
\hline Nonperforming loans & 250 & 136 & 119 & 49 & 45.5 & 57.7 \\
\hline $\begin{array}{l}\text { of which: bad debts } \\
\text { (sofferenze) }\end{array}$ & 144 & 58 & 62 & 35 & 59.7 & 74.5 \\
\hline
\end{tabular}

\section{The length of the recovery period represents a major negative factor for all NPL} reduction strategies. The long delays in collection and the low rate of recovery also affect the other approaches to deal with NPLs: the sale of NPLs and the restructuring of loans. From the point of view of the market of NPLs, there is a clear impact of the time of recovery of claims on the price of NPLs. ${ }^{11}$ The delays depreciate the value of the NPLs, and the prices buyers are ready to pay, after discounting the delays, are not attractive for the banks. A reduction in the time to recover loans would have a positive impact in the price of NPLs. ${ }^{12}$ Finally, the delay in enforcement also interferes with debt restructuring strategies, since creditors cannot negotiate from a position of strength, and recalcitrant debtors have no incentives to make sacrifices in the absence of the threat of swift seizure of their assets.

\section{LEGAL ISSUES AND REFORMS}

\section{The reform of the legal system is one of the key aspects for the resolution of corporate distress in Italy. It is generally accepted that inefficiencies in the legal system have contributed to the aggravation of the corporate distress and NPL situation, instead of}

\footnotetext{
${ }^{10}$ Source: Banca d'Italia (2016). The book value of collateral tends to be higher than the value of the loans. It is also noticeable that an additional 17 percent of nonperforming loans benefit of personal guarantees. Naturally, the legal position of a creditor provided with a personal guarantee is entirely different from the position of creditors with security interests.

${ }^{11}$ See Jobst, A. and Weber, A. (2016).

${ }^{12}$ However, the impact may be difficult to quantify. See Ciavoliello, L. G., and others, (2016) for a model that quantifies the increase in the price of the NPLs as an effect of the reduction in time to enforce NPLs. According to their model, the authors conclude that a reduction in the time of recovery from six years to five years would increase the price of NPLs from 12.9 percent to 16.1 percent of the gross book value of the loans (the model assumes an IIR of 20 percent). A reduction to four years would raise the price to 19.8 percent, to three years would set a 24.4 percent price, to two years to 29.8 percent, and if the collection time would be reduced to one year, the estimation is that the price of NPLs would reach 36.3 percent of the nominal value of the loans. It is unclear whether the model takes into account the existence and value of the collateral, or if it refers only to unsecured loans. Cerved (2015) develops a different model for the pricing of NPLs, also giving substantial weight to the time to recover. Equita SIM has estimated that a reduction of just one year in time to collect could increase the value of secured NPLs by more than 2 percent.
} 
alleviating them. There is also consensus that legal reforms are necessary to tackle the problem: strengthening the legal framework for debt resolution is one of the key components of a comprehensive strategy to reduce NPLs and to address the corporate debt overhang. ${ }^{13}$

\section{The Italian authorities have introduced numerous reforms with the goal of improving the efficiency of the system. Aware of the problems in the insolvency and enforcement} framework, they have engaged in a series of significant reforms of the legal framework; since the major insolvency reform of 2005, there have been additional reforms of the Italian insolvency framework in 2007, 2009, 2012, 2015, and 2016 (see Box 1). This series of reforms has introduced multiple changes to the original insolvency law (legge fallimentare of 1942), whose initial design is barely recognizable nowadays.

\section{Box 1. Insolvency Reforms in Italy (2005-2016)}

2005-2006: Concordato preventivo becomes a reorganization process, following other reforms in the USA and in several European countries. Possibility of sale of the enterprise as a going concern in insolvency. Introduction of the restructuring agreement and the rescue plan.

2007: Enlargement of the scope of the enterprise insolvency regime, coordination of reorganization plan and liquidation plan, registration of professionals to assess insolvency plans, restrictions to the liability of the creditors' committee.

2009: Reductions of the powers of the court; increase of powers of the insolvency administrator and the creditors' committee. Contents of the insolvency administrators' report, preparation of the liquidation plan.

2012: Easier use of restructuring agreements and rescue plans; provisions for bridge financing and temporary stay of creditor actions; protection against avoidance actions; reorganization plans with continuity of the business. Possibility of entering the reorganization process without a plan (concordato in bianco), improvement of the provisions to disclaim executory contracts.

2015: Competing plans in reorganizations; specific timeline for the completion of tasks by the insolvency administrator; more flexibility in the sale of assets (shorter delays, use of experts, less auctions, assignment to creditor, payment by instalments); financial restructuring agreements.

2016: Out-of-court enforcement of secured claims in commercial lending relationships; reduction of delays in auctions; reform of security interests over movables; use of electronic communications in insolvency.

Rordorf proposal (2015): Reorganization of the insolvency law, including the harmonization of the common phase of all procedures; concentration of insolvency jurisdiction in the Enterprise courts and the largest civil courts; acceleration of the treatment of enterprise crisis by means of the "alert procedure."

\section{The reforms have sought to increase the speed and efficiency of insolvency and} enforcement procedures. This is clear with reforms that penalize the insolvency administrator for the delay of the process. The latest reforms are still being implemented, and it is premature to assess their impact. Some commentators have argued that the 2015 reforms could reduce the time to complete a bankruptcy process by more than two years (from six to three or four years) and the time to complete an enforcement action by one year (from four to three years), although these are mere estimations. ${ }^{14}$ Another declared objective of the latest

\footnotetext{
${ }^{13}$ See Aiyar, S., and others (2015).

${ }^{14}$ Marcucci, M., Pischedda, A. and Profeta, V. (2015) estimate that the average length of the bankruptcy process, from the declaration of insolvency to the final distribution of the proceeds resulting from liquidation,
} 
reforms is the promotion of reorganization (concordato preventivo) as the favored alternative against the liquidation of enterprises. However, the number of reorganization cases is still low, and has even experienced a reduction (see Figure 2).

\section{In particular, the reforms have improved the position of creditors in insolvency} procedures. The changes introduced in 2015 have increased the influence of creditors in the reorganization process, allowing them to present alternative plans, and allowing creditors to participate more actively in the sale of assets. The reforms in the last two years reverse the course of the previous ones, especially the reforms of the law introduced in 2006 and 2012, which were pro-debtor.

\section{The latest reform of enforcement procedures (2016) represents a breakthrough, by introducing out-of-court enforcement for secured loans granted to enterprises. The} technique adopted has been the so-called "Martian pact," 15 according to which the creditor can appropriate the collateral or force its sale, but must always compensate the debtor for any excess value of the collateral once the loan is satisfied. This represents a fundamental innovation in Italian law: ${ }^{16}$ the mechanism avoids the lengthy court procedures and has the potential of reducing the time to collect to a period counted in months, instead of years. ${ }^{17}$ The reform also introduces new non-possessory security interests over movable assets, with flexibility in its creation and enforcement. This reform will surely increase access to finance for enterprises, especially SMEs. ${ }^{18}$

\section{The frequent and sudden modifications of the law have, however, come at a cost of} undermining legal certainty. The reforms were adopted using emergency mechanisms (decree-laws). While the severity of the economic situation can explain the use of such instruments, it is normally preferable to follow ordinary legislative procedures, with

\footnotetext{
should drop from more than six to around three years in a favorable scenario of effective implementation (around 4-5 in a less favorable one); the overall average length of the judicial foreclosures should drop from more than four to around three years. Cerved (2015) argued that timescales could be reduced by 28 percent for bankruptcy procedures and by 20 percent for public real estate auctions, thus reducing the total average time frame for extinguishing bad loans from 7.3 years to 6 years.

15 This contractual provision is named after the classic Roman lawyer Martian, and it is considered an equitable alternative to the notorious "lex commissoria" pact, i.e., a contractual provision that would allow the creditor to appropriate the collateral, irrespective of the difference in value between the loan and the collateral. In the Martian pact, the creditor must indemnify the debtor for the difference in value as assessed by an independent expert's evaluation to be made after the non-payment event.

${ }^{16}$ However, out of court enforcement was not entirely unknown in Italy- the legislative decree n.170 (2004) allows out-of-court enforcement of financial collateral, and the art. 2803 of the civil code allows the out-ofcourt enforcement of pledges over receivables.

${ }^{17}$ The Italian Ministry of Finance has provided a detailed calculation according to which the time to enforce will be reduced to a seven month period (Ministero dell'Economia e Finanze, 2016).

${ }^{18}$ See Calomiris and others, (2016); Garrido, J., Kopp, E., and Weber, A. (2016); and references included.
} 
appropriate consultation, to introduce changes to private law, ${ }^{19}$ even if those procedures take more time. The introduction of piecemeal changes to existing legislation can add to legal uncertainty. The authorities acknowledge the need to take stock of these reforms and rearrange the insolvency legislation in a systematic way. To this end, the government created a commission composed of prestigious insolvency professionals and academics (Rordorf Commission). The Commission delivered a report and a proposal to reconstruct the insolvency regime in a coordinated fashion (2015). The legislative delegation by Parliament, based on the Rordorf commission proposals, will allow for a much-needed systematization of the insolvency system. ${ }^{20}$

\section{REMAINING ISSUES AND RECOMMENDATIONS}

Despite the recent reforms, there are outstanding legal issues. The problems of the Italian insolvency framework are common to those of many Western European countries. Even some of the latest reforms of the Italian insolvency system have run parallel to some of the reforms in other European countries (France and Spain, for example). Apart from a number of technical issues that will have to be resolved, the main points that would deserve consideration refer to the integration and general operation of the insolvency system, and to the position of secured and unsecured creditors in insolvency proceedings.

The Italian insolvency system remains extremely complex. According to the survey conducted by Bank of Italy staff, banks indicated that court backlogs and the complexity of the procedures were the chief impediments to effective credit recovery. ${ }^{21}$ A simple illustration shows the highly intricate structure of the system, with multiple procedures performing similar functions and without clear transitions across some of the procedures (see Figure 4). ${ }^{22}$ This complexity does not result in higher efficiency or in more tailored solutions for different debtors. On the contrary, the complexity of the system, together with the uneven quality of the courts, can result in lack of predictability, unequal solutions and distorted incentives. In particular, some debt restructuring mechanisms seem duplicative: while the restructuring agreement comes very close to the pre-insolvency procedure recommended by the European

\footnotetext{
${ }^{19}$ The OECD has also made this general point about the use of decree-laws in Italy: see OECD (2015). There are some matters, such as the reform of security interests over movable assets, that are particularly ill-suited for its regulation in a decree-law; the reform requires implementation actions, such as the creation of the registry, that require, in every case, a longer time frame than the one provided by a decree-law.

${ }^{20}$ The Commission was established by the Minister of Justice in January 28, 2015 with a broad mandate of modernization of the Italian insolvency system. See the report of the Rordorf Commission and its legislative proposals at http://www.dirittobancario.it/news/fallimento-e-procedure-concorsuali/la-proposta-definitiva-dellacommissione-rordorf-la-riforma-delle-procedure-concorsuali. The Italian Government decided to submit to Parliament a proposal of a legislative delegation along the lines suggested by the Commission (Feb. 10, 2016).

${ }^{21}$ See Carpinelli, L., and others (2016).

${ }^{22}$ Figure 4 is a simplified presentation of the system: there are two additional procedures to handle crises in large enterprises (amministrazione straordinaria, in the special versions of the laws Prodi and Marzano), and a special liquidation procedure (liquidazione coatta) which applies to supervised entities, but also to some types of enterprise (cooperative societies).
} 
Union, ${ }^{23}$ the "rescue plan" can hardly qualify as a debt restructuring mechanism and raises some concerns regarding its effectiveness and the treatment of creditors. ${ }^{24}$ The recent addition of the financial debt restructuring agreement creates more complexity - a single type of general debt restructuring agreement with creditors divided in classes should be sufficient to cover the need for a hybrid debt restructuring instrument (and could in fact be a result after the systemization of the insolvency law). Another area that raises concerns is the lack of a full connection between some of the debt restructuring mechanism and the formal insolvency process. For instance, a debtor that does not comply with a rescue plan, or a debt

Figure 4. The Italian Insolvency System

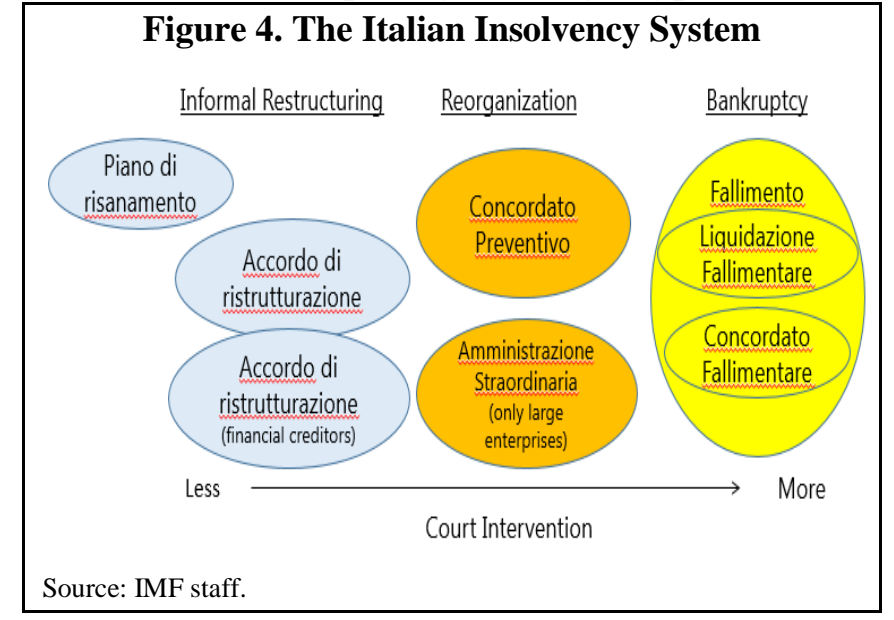
restructuring agreement, does not find itself in a situation where there is a smooth transition to a more formal insolvency process.

\section{The complexity of the insolvency system provides opportunities for the use of delaying} tactics. The multiple debt restructuring options tend to be used by debtors primarily to delay an inevitable liquidation. There is some anecdotal evidence suggesting that debtors avoid the debt restructuring options that require publicity and difficult concessions to creditors. Therefore, when considering the duration of the insolvency process, it would be appropriate to take into account that, in many cases, a long period of time has already been spent in using different mechanisms before the debtor runs out of alternatives and is finally pushed to bankruptcy. ${ }^{25}$ This accentuates the issue of the time to recover and also explains the low rate of recovery in insolvency cases, since the situation of debtors deteriorates seriously before the formal insolvency process is accessed.

A simplified insolvency system would be more efficient. The current insolvency law has been subject to numerous reforms, especially in the last decade, and a comprehensive revision of the insolvency framework would provide order, coherence, and a closer alignment

\footnotetext{
${ }^{23}$ See EC Recommendation on a New Approach to Business Failure and Insolvency (March 12, 2014).

${ }^{24}$ The rescue plan is an example of a "discreet" arrangement that does not necessarily require any degree of publicity and that can result in the improvement of the position of the creditor or creditors who participate in the agreement. The main effect of the rescue plan is, indeed, the protection of the creditors against a subsequent avoidance action in an insolvency process. There is some evidence that numerous rescue plans result in superficial restructurings whose effect is the protection of specific creditors, rather than providing a sustainable solution to the indebtedness of enterprises. The survey conducted by Carpinelli, L., and others (2016) among Italian credit institutions show that three quarters of rescue plans fail or have to be revised within a four-year period of their conclusion.

${ }^{25}$ Cfr. Bisogno, M., and De Luca, R. (2014) (stating how Italian SMEs avoid insolvency by all means and delay an insolvency filing as much as possible).
} 
with the objectives of the legislation itself. As noted above, the need to rationalize the latest reforms, providing more consistency to the system, was identified by the Italian authorities. There are numerous positive elements in the proposals of the Rordorf Commission which will need to be materialized in specific changes to the insolvency legislation once the government acts on a legislative delegation granted by Parliament. This also affects the special procedures for the reorganization of large enterprises (amministrazione straordinaria, in all its modalities), which should converge with the general insolvency procedures. ${ }^{26}$ In essence, the system should offer a clear path to enterprises, with specific solutions applicable to them depending on the severity of distress, and with a seamless transition from one mechanism to the next. Debt restructuring mechanisms work more effectively in a continuum with formal insolvency procedures. ${ }^{27}$

\section{The insolvency regime should also offer more flexible possibilities for restructuring.}

This should include recapitalizations and debt/equity swaps without shareholders' interference. The 2015 reform included some measures to address the problem, but they should be accompanied by a wider reflection of the role of individual shareholders, the shareholders' meeting and the debtor's directors in insolvency procedures. Measures to incentivize reorganization plans that are based on the continuation of the business must also be accompanied by solid principles that provide for adequate protection of creditors. Rules that establish a minimum percentage for repayment of creditors in reorganization planswith exceptions for plans based on the continuation of the enterprise-seem out of line with the basic principles that inspire the system. ${ }^{28}$ The Rordorf Commission has also identified the need for provisions facilitating the reorganization of enterprise groups.

\section{There is a "timing problem" in insolvency procedures: distress is addressed when it is} invariably too late. In general terms, procedures should be initiated at an earlier stage, increasing the restructuring and recovery possibilities. In the Italian system, there are a high number of liquidations and a low proportion of reorganization cases. Despite the efforts to increase the flexibility and speed of reorganization procedures, the success rate of reorganizations, at 4.5 percent of cases, is very low: ${ }^{29}$ the reorganization process works akin

\footnotetext{
${ }^{26}$ The procedures for special administration of large enterprises represent an anomaly in the European context, as a legacy of former times where State intervention in the economy was intense. These hybrid procedures (a mixture of judicial and administrative procedures) have resulted in diminished protection of creditor rights (see Marraffa, R., 2012).

${ }^{27}$ See Garrido, J. (2012).

${ }^{28}$ The reforms have resulted in a framework where reorganization plans must offer at least a 20 percent repayment rate for unsecured creditors, unless the plan foresees the continuation of the debtor's business (see Art. 160 of the legge fallimentare). This seems counter-intuitive since the main reason for the continuation of the business is the achievement of a more efficient economic outcome. See Bonelli, A., (2015) who criticizes the 20 percent rule as a "return to the past" and as a limitation of private autonomy. The explanation for the minimum percentage can only be found in the existence of past abuse.

${ }^{29}$ See Castelli, C., and others, (2016). In addition, the authors indicate that 77 percent of companies using the concordato in bianco (reorganization without immediate submission of a plan) do not present a plan in time.
} 
to a "slow-motion liquidation." The explanation is probably found, among other factors, in the delay in identifying and treating corporate distress. The Rordorf Commission was aware of the importance of this "timing problem" in Italy and recommended an approach based on an "alert procedure," fashioned after a similar procedure in the French system. This is an interesting approach that has not been followed in other countries, probably due to the interventionist undertones of the procedure. ${ }^{30}$ Generally, the preferred approach to resolve the "timing problem" is to establish proper incentives and disincentives for the debtor and its creditors. $^{31}$ The correct definition and application of liability provisions for directors would tend to reduce the timing problem in the use of the insolvency process, together with the general simplification of the system.

\section{There are ongoing reforms of the institutional framework for insolvency which require} prompt and adequate implementation. The latest reforms have focused on the specialization of the courts and the regime of insolvency administrators. The attribution of the competence over insolvency cases to the enterprise courts and the largest civil courts represents a key step toward specialization and needs to be quickly implemented. Changes to the regime of insolvency administrators, increasing their qualifications and accountability, also require effective implementation.

In assessing the latest reforms and the remaining issues, it is important to look at the position of secured and unsecured creditors. The connection between corporate debt and the levels of NPLs in the financial sector, and the fact that banks provide both secured and unsecured loans (see Table 1), require a closer analysis of the treatment of creditors in insolvency.

The time to recover secured claims in the insolvency process is still long. Some of the recent reforms have sought to accelerate the payments to creditors, independently of the resolution of other controversies that delay the general insolvency process. Insolvency processes should be further streamlined, reducing appeals and opportunities for delay, while, at the same time, providing for adequate protection for all participants (see Box 2 for a comparison between Italy and other European countries). This increase in efficiency requires a careful consideration of the details of the procedures, the specialization of the judiciary and the reinforcement of court officials and insolvency administrators. Courts across Italy should adopt best practices in court management to enhance their efficiency. Recent reforms have

\footnotetext{
${ }^{30}$ The "procédure d'alerte" can be invoked by diverse actors-including the auditors, the shareholders, or the workers' representatives - to require explanations and an action plan from the company's managers, when faced with extraordinary difficulties. This procedure can result in further actions-mediation to resolve the debt problems of the company. It is unclear how an alert procedure would be configured in Italian law.

${ }^{31}$ See Cornelli, F., and Felli, L. (1996) who note that the way to open bankruptcy procedures at the right time is to provide a system with penalties and incentives. Although the Italian system contemplates the potential liability of directors for their negligence in their conduct of the company in crisis, the contours of this liability are not entirely clear, since it is based on the general application of company law rules: see e.g., Lener, R., and Rosato, G. (2015).
} 
established firm deadlines, with consequences, in case of noncompliance, for the insolvency administrator. It remains to be seen whether this results in an acceleration of the insolvency process. The key measure to de adopted, in a future revision of the insolvency law, is the reduction of appeals to avoid excessive protection inside the process (tutela endofallimentare). ${ }^{32}$

\section{The introduction of out-of-court enforcement clearly improves the situation of secured creditors, but pitfalls must be avoided, and the reform of civil procedure should continue. The introduction of out-of-court enforcement in secured lending to enterprises,} introduced by the decree-law of May 3, 2016, will reduce dramatically the time to enforce, provided that the system is protected against judicialization: challenges to enforcement actions should operate ex-post, providing only a remedy for damages. The system must also strike the right balance between the right of the creditor to enforce its claim and the need to preserve the value of the enterprise in insolvency proceedings. ${ }^{33}$ While the abuse of the stay should be avoided, by restricting its scope and limiting its time, the stay is a necessary measure to preserve enterprise value, and both the protection of the secured creditor and the protection of enterprise value must be reconciled. ${ }^{34}$ In addition, the introduction of out-ofcourt enforcement should not diminish the need to implement the reform agenda at the civil courts: the government should continue promoting alternative dispute resolution techniques, streamlining the procedures (see a comparison with other European countries in Box 3), introducing better information technology and reinforcing the auxiliary staff of the courts with personnel from other sector of the public administration. The development of court performance indicators and best practices (Project Strasbourg 2.0) aims at reducing the gap between the best managed courts and those which are underperforming — which represent a majority in certain geographical areas. In the context of the reform of civil procedure, a key priority should be the reform of the appeal system, restricting the type of cases that reach the Supreme Court (Corte di Cassazione).

The increased flexibility in the sale of assets should be implemented effectively. The sale of assets should be supported by the use of mechanisms such as Internet platforms. Steps have been taken in this direction with the creation of an electronic portal for sales, which should be implemented before the end of 2016. The project "Common" would complete the system by delivering tradeable certificates to creditors, corresponding to the projected value of their claims. Creditors will be able to trade the certificates or to use them to bid for other

\footnotetext{
${ }^{32}$ In fact, the key decisions that should be subject to a rapid appeal are the access to the process and the exit from it: see Fabiani, M. (2015).

${ }^{33}$ The decree-law (Art. 2.12) mentions that the creditor will have the right to enforce even in the case of bankruptcy (fallimento) of the debtor. The decree-law does not mention the effects of other procedures (such as reorganization), but it is understood that the stay that accompanies the reorganization efforts will also apply to this new security interest.

${ }^{34}$ See Garrido, J. M. and Smith, E. E. (2016).
} 
assets for sale, instead of waiting for the conclusion of the liquidation to obtain satisfaction of their claims. This is an innovative project that deserves serious study and consideration.

\title{
The main problem for unsecured creditors is the proliferation of privileges in the
}

insolvency process. While the main concern for secured creditors is the delay in the recovery of their claims, the key issue for unsecured creditors is the low rate of recovery, which is due to several factors (cost of the process, severity of the enterprise distress), but specifically to the existence of a long list of preferential claims that virtually absorb the available proceeds. ${ }^{35}$ The Rordorf report proposes a revision of creditor priorities, and this revision should provide more space to the satisfaction of unsecured claims.

\section{Finally, the overall impact of the reforms will affect more the flow of nonperforming} loans than the existing stock. The reform allowing for out-of-court enforcement only applies to new lending relationships, or to renegotiated loans. It must be considered, however, that the possibilities to renegotiate decrease when the debtor finds itself already in financial distress. It is also true that the reduction of the flow of cases would allow the judiciary to concentrate on the litigation related to the existing stock of NPLs. However, it is also clear that it will not be possible to process the large number of distressed companies through the court system. ${ }^{36}$

\begin{abstract}
Alternative approaches to the judicial resolution of insolvency cases must be explored in order to resolve the situation of corporate debt distress. Given the limitations of the judicial resources, and the urgency in addressing the situation of corporate debt, the alternative approaches to insolvency should be reinforced. For large debtors, banks should cooperate in the development and application of debt restructuring principles, ${ }^{37}$ and utilize debt restructuring mechanisms with minimal court intervention. The clarity of the law is a fundamental element to provide a backdrop for efficient negotiation. ${ }^{38}$ For SMEs, banks should perform a triage establishing the viability of SMEs according to basic objective indicators, and proceed to the restructuring of the viable businesses and the liquidation
\end{abstract}

\footnotetext{
${ }^{35}$ The lack of statistical data implies that the affirmation in the text is based on anecdotal evidence and interviews with economic actors and legal experts. The fact that the requirement of a 20 percent recovery rate for certain insolvency plans has been met with resistance is a very good indication that the expectation among participants is that the proceeds of the insolvency process are absorbed by preferential creditors, and unsecured creditors receive less than that percentage. A peculiarity of the Italian system is that, owing to the complexities and delays of civil procedure, unsecured creditors may receive an earlier payment in an insolvency process than in an ordinary civil enforcement action. However, the amount recovered in an insolvency process can be insignificant.

${ }^{36}$ According to data provided by the Ministry of Economic Development, there were more than 200,000 vulnerable enterprises in 2015. According to data collected by Cerved, there are around 81,000 enterprises classified as high risk, and 193,000 enterprises classified as vulnerable.

${ }^{37}$ These principles should reflect best international practices: an example is the INSOL global principles for multi-creditor workouts. The Italian Bank Association (ABI) made a first attempt at the development of debt restructuring principles in 2000 , but the initiative was not successfully completed.

${ }^{38}$ See Hagan, S. (2010); Laryea, T. (2010); and Liu, Y. and Rosenberg, C. (2013).
} 
of those that are unviable. ${ }^{39}$ The recent introduction of tax rules that exempt debt forgiveness from being considered taxable income provides an attractive incentive for debt restructuring. ${ }^{40}$

\section{Conclusions}

The reforms of the insolvency and enforcement framework adopted in the last year signal an improvement in the legal environment of credit in Italy. The reforms will require adequate implementation, and the effects of some of the reforms are expected to be felt only in the medium to long term. The reforms, however, were introduced through emergency measures (decree-laws) that resulted in numerous piecemeal changes to the insolvency system, which affects legal certainty. There is thus an urgent need for a comprehensive reform to harmonize the legislation.

The recent deep changes in the enforcement of secured claims will have more impact on the flow of nonperforming loans than on the existing stock of NPLs. If implemented properly, the out-of-court enforcement mechanism will reduce the time to collect secured loans in a significant way. However, the effects on the stock of NPLs can only be indirect, through the voluntary submission of debtors to the new regime, or by allowing courts to concentrate their resources on the existing cases.

Alternative approaches based on debt restructuring could be used to address corporate debt distress and reduce the existing stock of NPLs. The use of informal debt restructuring techniques for the large cases, supported by the possible confirmation of informal plans through the courts, and a triage of the smaller companies, would assist in providing a timely solution for the widespread situation of corporate debt distress.

The continuation of the ambitious reform agenda is necessary. The rationalization of the insolvency system, and the reinforcement of the institutional framework - based on the attribution of competence to the enterprise courts and the professionalization of insolvency administrators - are ambitious reforms that should be pursued. Equally, the reforms to civil procedure, including the introduction of a marketplace for the sale of assets in insolvency and enforcement cases, and the reform of the secured transactions framework, should be pursued.

\footnotetext{
${ }^{39}$ See Bergthaler, W. and others (2015).

${ }^{40}$ See Art. 14 DL February 14, 2016 n.18, transformed into law on April 8, 2016, n.49.
} 


\begin{tabular}{|c|c|c|c|c|}
\hline \multicolumn{5}{|c|}{ Box 2. Enforcement of Secured Credit in Insolvency_Key Elements in Compared Systems } \\
\hline & Italy & France & Germany & Spain \\
\hline $\begin{array}{l}\text { Limited scope } \\
\text { of the stay of } \\
\text { creditor actions }\end{array}$ & $\begin{array}{l}\text { No. Unrestricted } \\
\text { scope. }\end{array}$ & $\begin{array}{l}\text { Broad stay, with some } \\
\text { exceptions (pledge } \\
\text { over receivables, } \\
\text { reservation of title, } \\
\text { fiduciary agreements). }\end{array}$ & $\begin{array}{l}\text { Yes. The stay does not } \\
\text { apply to numerous } \\
\text { security interests. }\end{array}$ & $\begin{array}{l}\text { Yes. Asset must be } \\
\text { necessary for the } \\
\text { continuation of the } \\
\text { debtor's business. }\end{array}$ \\
\hline $\begin{array}{l}\text { Time limits for } \\
\text { the stay }\end{array}$ & $\begin{array}{l}\text { Only in certain } \\
\text { procedures: } 120 \\
\text { days in } \\
\text { restructuring } \\
\text { agreements; Max. } \\
8 \text { months in } \\
\text { concordato } \\
\text { preventivo; } 2 \text { years } \\
\text { in amministrazione } \\
\text { straordinaria; } \\
\text { however, } \\
\text { unlimited stay in } \\
\text { insolvency. }\end{array}$ & $\begin{array}{l}\text { Informal procedures } \\
\text { can be supported by } \\
\text { stays of up to } 2 \text { years. } \\
\text { In reorganization } \\
\text { (sauvegarde, } \\
\text { redressement), the } \\
\text { observation period } \\
\text { may last up to } 12 \\
\text { months. In insolvency, } \\
\text { the stay can last for } \\
\text { most of the process. }\end{array}$ & $\begin{array}{l}3 \text { months for informal } \\
\text { procedures. For } \\
\text { insolvency, } \\
\text { unspecified, but with } \\
\text { possibility of relief by } \\
\text { the court. }\end{array}$ & $\begin{array}{l}\text { Yes: Max. } 1 \text { year (in } \\
\text { the insolvency } \\
\text { process). Possibility to } \\
\text { sell the collateral } \\
\text { before the end of the } \\
\text { period. }\end{array}$ \\
\hline $\begin{array}{l}\text { Protections } \\
\text { against the stay }\end{array}$ & $\begin{array}{l}\text { Yes: Interest } \\
\text { accrues up to the } \\
\text { value of the } \\
\text { collateral. }\end{array}$ & $\begin{array}{l}\text { Limited, interest } \\
\text { accrues only loan } \\
\text { contracts for terms of } \\
\text { more than one year. }\end{array}$ & $\begin{array}{l}\text { Yes, interest accrues } \\
\text { up to the value of the } \\
\text { collateral. }\end{array}$ & $\begin{array}{l}\text { Yes: Interest accrues } \\
\text { up to the value of the } \\
\text { collateral. }\end{array}$ \\
\hline $\begin{array}{l}\text { Limited } \\
\text { appeals against } \\
\text { decisions } \\
\text { within the } \\
\text { insolvency } \\
\text { process }\end{array}$ & $\begin{array}{l}\text { Broad possibilities } \\
\text { for appeal, } \\
\text { including appeals } \\
\text { to the Supreme } \\
\text { Court. }\end{array}$ & $\begin{array}{l}\text { Limited appeals on } \\
\text { certain decisions and } \\
\text { only to certain courts. }\end{array}$ & $\begin{array}{l}\text { Yes, there is a list of } \\
\text { acts subject to appeals } \\
\text { inside the insolvency } \\
\text { process. }\end{array}$ & $\begin{array}{l}\text { Yes. There is no } \\
\text { appeal for most } \\
\text { decisions, only one } \\
\text { appeal to the district } \\
\text { court of appeal. }\end{array}$ \\
\hline $\begin{array}{l}\text { Valuation of } \\
\text { collateral }\end{array}$ & Unclear. & $\begin{array}{l}\text { Imperfect valuation } \\
\text { rules. }\end{array}$ & $\begin{array}{l}\text { Yes, implicit in } \\
\text { numerous rules. }\end{array}$ & $\begin{array}{l}\text { Yes. In the submission } \\
\text { of claims. }\end{array}$ \\
\hline $\begin{array}{l}\text { Creditor } \\
\text { control over the } \\
\text { sale }\end{array}$ & Limited. & $\begin{array}{l}\text { Very limited. The sale } \\
\text { can be conducted } \\
\text { without creditor } \\
\text { intervention and the } \\
\text { proceeds are kept om } \\
\text { escrow for the creditor. }\end{array}$ & $\begin{array}{l}\text { Yes, but only during a } \\
\text { period of time. } \\
\text { Otherwise, the sale is } \\
\text { controlled by the } \\
\text { insolvency } \\
\text { administrator. }\end{array}$ & $\begin{array}{l}\text { The court can } \\
\text { authorize special sales } \\
\text { under control of the } \\
\text { creditor. Otherwise, } \\
\text { auction within the } \\
\text { insolvency process. }\end{array}$ \\
\hline
\end{tabular}




\begin{tabular}{|c|c|c|c|c|}
\hline \multicolumn{5}{|c|}{ Box 3. Individual Enforcement of Secured Credit-Key elements in Compared Systems } \\
\hline & Italy & France & Germany & Spain \\
\hline $\begin{array}{l}\text { Out of court } \\
\text { enforcement } \\
\text { possible }\end{array}$ & $\begin{array}{l}\text { Since May 2016, } \\
\text { possible with } \\
\text { contract }\end{array}$ & Yes, by contract. & $\begin{array}{l}\text { No, only judicial } \\
\text { enforcement. }\end{array}$ & Yes, by contract. \\
\hline $\begin{array}{l}\text { Summary } \\
\text { procedure }\end{array}$ & $\begin{array}{l}\text { Ordinary } \\
\text { procedure }\end{array}$ & $\begin{array}{l}\text { Special summary } \\
\text { process }\end{array}$ & $\begin{array}{l}\text { Special summary } \\
\text { process }\end{array}$ & $\begin{array}{l}\text { Special summary } \\
\text { process }\end{array}$ \\
\hline $\begin{array}{l}\text { Limited } \\
\text { appeals (and } \\
\text { no suspension } \\
\text { effect) }\end{array}$ & $\begin{array}{l}\text { Appeals available } \\
\text { at several stages, } \\
\text { including appeal to } \\
\text { the Supreme } \\
\text { Court. }\end{array}$ & $\begin{array}{l}\text { Appeals are processed } \\
\text { on a fast-track. } \\
\text { Generally, no } \\
\text { suspension effects. }\end{array}$ & $\begin{array}{l}\text { Few appeals, generally } \\
\text { no suspension effects. }\end{array}$ & $\begin{array}{l}\text { One appeal, generally } \\
\text { no suspension of } \\
\text { effects. }\end{array}$ \\
\hline $\begin{array}{l}\text { Suspensions of } \\
\text { process }\end{array}$ & Frequent & Very limited & Extremely limited & Extremely limited \\
\hline $\begin{array}{l}\text { Possibility of } \\
\text { dispensing with } \\
\text { the auction }\end{array}$ & $\begin{array}{l}\text { The procedure can } \\
\text { end with an } \\
\text { auction or with a } \\
\text { sale after } \\
\text { submission of an } \\
\text { offer. }\end{array}$ & $\begin{array}{l}\text { Private sale possible } \\
\text { only with the debtor's } \\
\text { consent (for } \\
\text { mortgages). }\end{array}$ & $\begin{array}{l}\text { Generally, auction (for } \\
\text { mortgages). A private } \\
\text { sale can be agreed as } \\
\text { an alternative to the } \\
\text { auction. }\end{array}$ & $\begin{array}{l}\text { The new system } \\
\text { foresees electronic } \\
\text { auctions for all } \\
\text { procedures, in-court } \\
\text { and out-of-court. }\end{array}$ \\
\hline
\end{tabular}




\section{References}

Aiyar, S., Bergthaler, W., Garrido, J., Ilyina, A., Jobst, A., Kang, K., Kovtun, D., Liu, Y., Monaghan, D., and Moretti, M., 2015, “A Strategy for Resolving Europe's Bad Loans," IMF Staff Discussion Note 15/19 (Washington: International Monetary Fund).

Auricchio, A., and Gismondi, R., 2015, "The Italian Expedited Restructuring Remedies and Proceedings," in Expedited Corporate Restructuring in the EU, ed. by R. OlivaresCaminal (Oxford).

Banca d'Italia, 2016, Financial Stability Report 1/2016 (April).

Bergthaler, W., Kang, K., Liu, Y., and Monaghan, D., 2015, “Tackling Small and MediumSized Enterprise Problem Loans in Europe," IMF Staff Discussion Note 15/04 (Washington: International Monetary Fund).

Bisogno, M., and De Luca, R., 2014, "Bankruptcy Efficiency and Indirect Costs in Italian SMEs: a Temporal Approach," International Journal of Business Research and Development, Vol. 3, No. 2.

Bonelli, A., 2015, "Decreto "fallimenti", tra ritorno al "passato" e allineamento agli standard internazionali," in Ipsoa.it.

Budina, N, Lanau, S., and Topalova, P., 2015, "The Italian and Spanish Corporate Sectors in the Aftermath of the Crisis," IMF Country Report No. 15/167 (Washington: International Monetary Fund).

Calomiris, C.W., Larrain, M., Liberti, J., and Sturgess, J. (2016), "How Collateral Laws Shape Lending and Sectoral Activity," available at https://www0.gsb.columbia.edu/faculty/mlarrain/papers/CLLS.pdf.

Castelli, C., Micucci, G., Rodano, G., and Romano, G., 2016, "Il Concordato Preventivo in Italia: Una Valutazione Delle Riforme e Del Suo Utilizzo," Questioni di Economia e Finanza (Banca d'Italia), No. 316.

Cerved, 2015, Cerved SMEs Report (Rome).

Cerved, 2016, Osservatorio su fallimenti, procedure e chiusure di imprese, 4th Quarter 2015.

Cornelli, F., and Felli, L., 1996, "Ex ante Efficiency of Bankruptcy Procedures," SSRN Working Paper, available at http://ssrn.com/.

CEPEJ (Council of Europe), 2014, Report on European Judicial Systems: Efficiency and Quality of Justice, available at http://www.coe.int/t/dghl/cooperation/cepej/evaluation/2014/Rapport_2014_en.pdf. 
Carpinelli, L., Cascarino, G., Giacomelli, S. and Vacca V., 2016, "The Management of Nonperforming Loans: a Survey Among the Main Italian Banks," Questioni di economia e finanza (Banca d'Italia), No. 311.

Ciavoliello, L. G., Ciocchetta, F., Conti, F.M., Guida, I., Rendina, A., and Santini, G., 2016, "What's the Value of NPLs?"Notes on Financial Stability and Supervision, No. 3. (Banca d'Italia).

Esposito, G. L., Lanau, S., and Pompe, S., 2014, “Judicial System Reform In Italy-A Key to Growth,” IMF Working Paper 14/32 (Washington: International Monetary Fund).

European Commission, 2014a, Commission Recommendation on a New Approach to Business Failure and Insolvency (12.3.2014), C(2014) 1500 final, available at http://ec.europa.eu/justice/civil/files/c_2014_1500_en.pdf.

$\longrightarrow, 2014 \mathrm{~b}$, Impact Assessment accompanying the document

Commission Recommendation on a New Approach to Business Failure and Insolvency, available at http://ec.europa.eu/justice/civil/files/swd_2014_61_en.pdf.

—_, 2016, The 2016 EU Justice Scoreboard, Brussels.

Fabiani, M., 2015, “L’ipertrofica Legislazione Concorsuale Fra Nostalgie e Incerte Contaminazioni Ideologiche," Crisi d'impresa e fallimento, II, 1 ff.

Garrido, J. M., 2012, Out-of-court Debt Restructuring (Washington: World Bank).

Garrido, J., Kopp, E., and Weber, A., 2016, "Cleaning-up Bank Balance Sheets: Economic, Legal, and Supervisory Measures for Italy," IMF Working Paper [forthcoming] (Washington: International Monetary Fund).

Garrido, J. M. and Smith, E. E., 2016, Comparative Approaches to the Enforcement of Secured Credit in Insolvency, on Festschrift Prof. Rod MacDonald, International and Comparative Secured Transactions Law (in press).

Hagan, S., 2010, "Restructuring Corporate Debt in the Context of a Systemic Crisis," 73 Law and Contemp. Probs., 1.

INSOL Europe, 2014, Study on a New Approach to Business Failure and InsolvencyComparative Legal Analysis of the Member States' Relevant Provisions and Practices, available at http://ec.europa.eu/justice/civil/files/insol_europe_report_2014_annexes_en.pdf.

INSOL International, Statement of Principles for a Global Approach to Multi-Creditor Workouts, available at https://www.insol.org/pdf/Lenders.pdf. 
International Monetary Fund, 1999, Orderly \& Effective Insolvency Procedures (Washington).

— , 2015a, "Italy: Staff Report for Article IV Consultation,” IMF Country Report 15/166 (Washington).

—_, 2015b, “Italy: Selected Issues,” IMF Country Report 15/167 (Washington).

Jobst, A., and Weber, A., 2016, “Are Italian Banks Sufficiently Profitable to Overcome their Asset Quality Challenges?” Italy: Selected Issues [forthcoming] (Washington: International Monetary Fund).

Lanau, S., Esposito, G., and Pompe, S. 2014, "Judicial System Reform in Italy-A Key to Growth," IMF WP/14/32 (Washington: International Monetary Fund).

Laryea, T., 2010, "Approaches to Corporate Debt Restructuring in the Wake of Financial Crises,” IMF Staff Position Note (Washington: International Monetary Fund).

Lener, R., and Rosato, G., 2015, "Italy," in Restructuring and Insolvency 2016, ed. by B. Leonard, 228 ff (Law Business Research).

Liu, Y. and Rosenberg, C., 2013, "Dealing with Private Debt Distress in the Wake of the European Financial Crisis: A Review of the Economics and Legal Toolbox," IMF Working Paper WP/13/44 (Washington: International Monetary Fund).

Marcucci, M., Pischedda, A. and Profeta, V., 2015, "The Changes of the Italian Insolvency and Foreclosure Regulation Adopted in 2015," Notes on Financial Stability and Supervision, No. 2 (Banca d'Italia).

Marraffa, R., 2012, Amministrazione Straordinaria Delle Grandi Imprese in Crisi e Tutela Dei Creditori (Torino).

Ministero dell'Economia e Finanze, 2016, “Con il DL 59/2016 Tempi Più Brevi Per il Recupero Crediti," available at http://www.tesoro.it/inevidenza/article_0206.html (accessed on 5/13/2016).

OECD, 2015, OECD Economic Surveys-Italy (February 2015, Paris).

Rordorf Commission: Report and Legislative Proposals, http://www.dirittobancario.it/news/fallimento-e-procedure-concorsuali/la-propostadefinitiva-della-commissione-rordorf-la-riforma-delle-procedure-concorsuali.

UNCITRAL, 2005, Legislative Guide on Insolvency Law (New York). 